\title{
Nursing education: challenges and perspectives in times of the COVID-19 pandemic
}

\author{
Educação em enfermagem: desafios e perspectivas em tempos da pandemia COVID-19
}

Educación en enfermería: desafíos y perspectivas en tiempos de la pandemia de COVID-19

Ana Luisa Brandão de Carvalho Lira' ORCID: 0000-0002-7255-960X

Edlamar Kátia Adamy" ORCID: 0000-0002-8490-0334

Elizabeth Teixeira"l ORCID: 0000-0002-5401-8105 Francisca Valda da Silva' ORCID: 0000-0002-6364-2241

'Universidade Federal do Rio Grande do Norte. Natal, Rio Grande do Norte, Brazil.

"Universidade do Estado de Santa Catarina. Chapecó, Santa Catarina, Brazil.

I' Universidade do Estado do Amazonas. Manaus, Amazonas,

Brazil.

How to cite this article: Lira ALBC, Adamy EK, Teixeira E, Silva FV. Nursing education: challenges and perspectives in times of the COVID-19 pandemic. Rev Bras Enferm. 2020; 73(Suppl 2):e20200683. doi: http://dx.doi.org/10.1590/0034-7167-2020-0683

\section{Corresponding author:}

Elizabeth Teixeira

E-mail: etfelipe@hotmail.com

EDITOR IN CHIEF: Dulce Barbosa ASSOCIATE EDITOR: Ana Fátima Fernandes

Submission: 06-21-2020

Approval: 08-29-2020

\section{ABSTRACT}

Objective: To discuss the challenges and perspectives of nursing education in times of the COVID-19 pandemic. Methods: Reflection study, with theoretical approach based on national and international publications, allied to the experience of researchers in the area of nursing education. Results: Four sections are identified: Nursing education: current affairs and perspectives; Education and technologies in time of pandemic: acceleration, alteration and paralysis; Difference between emergency, intentional and remote teaching; the return to the "new normality": new structuring axes and legal norms. Final considerations: The conclusion is that longstanding challenges have emerged with the pandemic, and the processes of acceleration, change and paralysis have marked education in these times Moreover, epidemiological, technological and psychological aspects should be more valued in the return to activities.

Descriptors: Nursing; Education, Nursing; Educational Technology; Pandemics; Coronavirus Infections.

\section{RESUMO}

Objetivo: Discutir sobre os desafios e perspectivas da educação em enfermagem em tempos da pandemia COVID-19. Métodos: Estudo reflexivo, com enfoque teórico pautado em publicações nacionais e internacionais, aliado à experiência das pesquisadoras na área de educação em enfermagem. Resultados: Identificam-se quatro seções, a saber: Educação em enfermagem: atualidades e perspectivas; Educação e tecnologias em tempo de pandemia: aceleração, alteração e paralisação; Diferença entre ensino remoto emergencial, intencional e ensino a distância; O retorno à "nova normalidade": novos eixos estruturantes e normativas legais. Considerações finais: Concluise que os desafios de longa data ficaram emergentes com a pandemia, e os processos de aceleração, alteração e paralisação marcaram a educação nestes tempos. Outrossim, aspectos de ordem epidemiológica, tecnológica e psicológica devem ser mais valorizados no retorno às atividades.

Descritores: Enfermagem; Educação em Enfermagem; Tecnologia Educacional; Pandemia; Coronavírus.

\section{RESUMEN}

Objetivo: Discutir sobre los desafíos y perspectivas de la educación en enfermería en tiempos de la pandemia de COVID-19. Métodos: Estudio reflexivo, con enfoque teórico pautado en publicaciones nacionales e internacionales, aliado a la experiencia de las investigadoras en el área de educación en enfermería. Resultados: Se identifican cuatro secciones, a saber: Educación en enfermería: actualidades y perspectivas; Educación y tecnologías en tiempo de pandemia: aceleración, alteración y paralización; Diferencia entre enseñanza remota de emergencia, intencional y educación a distancia; El retorno a la "nueva normalidad": nuevos ejes estructurantes y normativas legales. Consideraciones finales: Se concluye que los desafíos de larga fecha quedaron emergentes con la pandemia, y los procesos de aceleración, alteración y paralización marcaron la educación en estos tiempos. Además, aspectos de orden epidemiológica, tecnológica y psicológica deben ser más valorizados en el retorno a las actividades.

Descriptores: Enfermería; Educación en Enfermería; Tecnología Educacional; Pandemia; Coronavirus. 


\section{INTRODUCTION}

Sars-CoV-2 is the new coronavirus identified as an etiological agent of the disease called COVID-19, which began in Wuhan, China, in late 2019. Human infection with the new coronavirus was declared by the World Health Organization (WHO) in January 2020 as a public health emergency of international importance. It was characterized as a pandemic in March of the same year. The main strategies established by WHO were: stop transmission from human to human; identify, isolate and care for infected patients; accelerate the development of diagnostics, therapeutics and vaccines; carry out community awareness activities; and minimize social and economic impacts ${ }^{(1)}$.

The nurses, in order to meet these strategies, despite the lack of essential items such as quality personal protection equipment, use their knowledge and skills in providing necessary care in all phases of the disease, guide the population, especially the most vulnerable, and seek innovative solutions, respecting the safety of the patient and the team. Thus, they face the challenges to overcome the pandemic, as well as come out of it stronger ${ }^{(2)}$.

However, Nursing students and teachers do not always feel prepared to act in an integral way in this pandemic scenario ${ }^{(3)}$. The main weaknesses related to Nursing students are: lack of personal protective equipment in the practice scenario; health insurance; supervision of the preceptor; adequate development of all skills needed to complete the course ${ }^{(3)}$. The difference in access to information and communication technologies (ICT), among others, is also added ${ }^{(4)}$. In relation to the teacher, the issue related to the use and mastery of ICTs in a short period of time is particularly noteworthy ${ }^{(3)}$.

Students and teachers, in the context of the pandemic, experience challenges in the teaching-learning process, especially those related to the relevance of the student's presence in the health service, the fulfillment of social needs, with emphasis on the UHS, the completeness of care, the assessment based on knowledge, skills and attitudes, and the management of quality in health care and patient safety. Each Higher Education Institution (HEI) is responsible for evaluating its institutional organization conditions, as well as the epidemiological conditions in order to define the paths to be traced for the graduation courses in Nursing.

This article presents the following guiding questions: What are the challenges and perspectives of nursing education in times of the COVID-19 pandemic? What is the relationship between undergraduate nursing education and technology in this pandemic period? What is emergency, intentional and distance learning remote education? How will the return to the "new normal" be?

\section{OBJECTIVE}

To discuss the challenges and perspectives of nursing education in times of the COVID-19 pandemic.

\section{METHODS}

Reflective study with a theoretical approach, based on national and international publications, allied to the experience of researchers in the area of education in Nursing. The studies were searched between May and June 2020 in the Science Direct and Scopus databases, based on the following descriptors included in the Health Sciences Descriptors (DeCS): nursing, pandemics, education. The descriptors were combined using the Boolean AND operator. Inclusion criteria were: year of publication (2020); and access to the full text. Twenty publications, national and international, were identified, and after reading and analysis, nine were selected.

\section{NURSING EDUCATION: CURRENT AFFAIRS AND PERSPECTIVES}

The crisis situation in the world scenario, established by COVID-19, has demanded fast changes in the way of teaching in both undergraduate and graduate levels, as well as the cancellation of classes in some scenarios. The teachers and managers assumed the task of guaranteeing, besides the quality in the formation, strategies so that the students meet its requirements, recognizing the pressure faced by the nursing services in the search for competent professionals to assume the diverse roles exercised by the nurse ${ }^{(2)}$.

Brazil has today; registered in the electronic system for monitoring the processes that regulate education, e-MEC system, about 1,180 HEls that offer the graduation course in Nursing. Of these, 1,172 in the face-to-face mode, with 181,994 authorized vacancies; and 8 in the Distance Learning (EaD) mode, with 82,240 vacancies. Of the HEls that offer the course in the face-to-face mode, 148 are public, with 8,500 places authorized.

Faced with these numbers and the current pandemic scenario of the new coronavirus, the concern with the nurse's training profile emerges, with a view to meeting social demands, overcoming traditional teaching approaches, pointing out changes in paradigms and breaking with practices and beliefs that can make it difficult to make changes.

This profile is described in the NCG of the Nursing undergraduate courses, which value a formative process centered on care, assuring individuals, groups and the community of completeness through a formative process of nurses with autonomy, discernment and proactivity ${ }^{(5)}$.

However, the educational trends of the 21 st century are marked by scientific and technological integration, which allows the academic management of all actors, assisted by ICTs. These development strategies and academic perspectives are fundamentally generated by digital platforms, technologies and methods based on an educational scenario with new conditions for self-learning mediated by virtual environments.

There is the availability and intelligent potential necessary for nursing teachers to excel more and more and assume the use of ICT. This fact is seen as a challenge to the transformative processes necessary to face and achieve quality training in times of pandemic. However, it has become an opportunity in the eyes of those who advocate nursing education in the $E a D$ mode.

The movements, organized over the past years by the Brazilian Nursing Association (ABEn), the Federal Nursing Council (COFEn), the Intersectoral Commission on Human Resources and Labor Relations of the National Health Council (CIRHRT/NHC), have been vehemently opposed to this formative modality for the health area. 
The NHC was emphatic when it published Resolution n. 515, of October 7, 2016, placing itself against the authorization of any undergraduate course in the health area taught in the modality $E a D$. The council considers the losses that courses in this modality can offer to the quality of training of health professionals, as well as the risks that these professionals may cause to society. Immediately, in the medium and long term, this teaching modality will reflect in an inadequate formation, mainly in the teachingcommunity integration ${ }^{(6)}$.

The training for the UHS must be based on the health needs of the people and, for this, requires an interprofessional, humanistic, technical and practical training in person, permeated by this integration teaching-service-community, experiencing the diversity of scenarios and spaces of experiences and practices, which will be prevented and committed in the modality $E a D^{(5)}$.

At this moment, it is considered important to analyze very carefully the adoption, after the pandemic, of the models currently implemented in the teaching-learning process assisted by technologies, so as not to migrate to the EaD modality, but to use it as a complement in the development of skills for academic training and especially for continuing education.

The fragilities that can affect the formation in nursing concern mainly the scope of the practical activities and internships. Nursing training requires the establishment of bonds of trust, allowing care and guidance in real practice scenarios. "In the art and science of care, nursing combines technical and humanistic knowledge necessary to enhance sensitivity to deal with human fragilities and needs ${ }^{(5)}$.

NCGs common to health courses emphasize the importance of service-community teaching integration, with the purpose of strengthening academia relations with services and the community, articulating the early insertion of students in real practice settings and service workers in the teaching-learning process ${ }^{(5)}$. Furthermore, the specific NCGs of the Nursing degree reinforce the importance of processes of formation of nursing professionals focused on caring for them, highlighting the need for pedagogies that strengthen the autonomy, participation, dialogue and political, critical and reflective engagement of future nurses.

\section{EDUCATION AND TECHNOLOGIES IN TIMES OF A PAN- DEMIC: ACCELERATION, CHANGE AND PARALYSIS}

From a historical perspective, it is possible to affirm that three events cause the acceleration of processes: wars, revolutions and pandemics. It is precisely from this perspective that what happened with education and technology in times of pandemics is highlighted.

Considering the teaching-research-extension tripod, the authors, based on their participation in events held since the period when the interruption of activities due to the pandemic was triggered, observed, in higher education in particular, two movements. In the public HEls, in the field of education, there was initially a deceleration, and in some cases there was a total paralysis of activities; in research, however, there was an acceleration, because the number of research projects approved by the system of the Research Ethics Council of the National Commission on Ethics in Research (CEP-CONEP) increased significantly during this period; in the extension there was also acceleration, and numerous actions both in solidarity and continuing education were initiated, offered both to the internal community of HEls, teachers and students, and to the general population and health workers. These actions were also disseminated in different media (social networks and television network).

In private HEls, in the field of education, there was no deceleration as in public, but a change in modality; activities migrated from face-to-face teaching to emergency remote teaching, and thus teachers and students continued to carry out activities mediated by communication and information technologies; in the field of research and extension, as in public HEls, there was also an acceleration.

Internationally, Athabasca University in Canada also made the difficult decision to remove its students from clinical internships, which only continued online learning. The authors state that although this university does not experience the same challenges that other academic institutions have faced in relation to distance to begin learning in a digital environment, the decision was difficult because, ethically, it had to consider the value of education against the risk and effort of the student, personally and professionally ${ }^{(7)}$.

The Ministry of Education published, in the DOU of April 6th, the Ordinance n. 374, of April 3rd, 2020, which allowed the anticipation of the graduation if $75 \%$ of the workload of the supervised internship activity for Nursing, Physiotherapy and Pharmacy is fulfilled; and the internship, for Medicine. The measure was justified by the confrontation of the public health emergency of international importance due to the new coronavirus, responsible for the outbreak started in 2019. Also noteworthy is Provisional Measure No. 934, of April 1, 2020, which establishes exceptional standards on the school year of basic education and higher education resulting from measures to address the pandemic COVID-19.

In the sphere of technologies, with emphasis on technologies for care, communication processes, modes of conduct and education, considering the classification of specific technologies for nursing ${ }^{(8)}$, there is an acceleration to respond to the emerging needs of the pandemic.

With regard to the instrumental-material components (hard technologies), the personal protective equipment stood out, and the production-use of different formats took place practically all over the national territory. As for the informational relational components (light-duty and light technologies), there is an intense production/distribution of books, manuals and booklets, as well as the dissemination/realization of "LIVES". Regarding the technologies, it is worth mentioning that, until mid-April, the emphasis was on the epidemiological aspects; since then, the emphasis has been on the psychological aspects for facing the pandemic.

It became evident that "it did not stop", only the speed of the processes was changed; in this period, knowledge and technologies were produced; in these months of the pandemic, new relationship modalities were learned; and the next post-pandemic period is already being glimpsed, for which a return to what has been called "new normality" is already being planned. Such reflections point out that longstanding challenges have been emerging with the pandemic, and the processes of acceleration, alteration and paralysis have marked education in these times. 


\section{DIFFERENCES BETWEEN EMERGENCY REMOTE EDUCA- TION, INTENTIONAL AND DISTANCE LEARNING}

This current pandemic moment, as has already been highlighted, has accelerated the adoption of technologies in higher education, and it is important to highlight two elements in this scenario: the development of learning spaces in a short period of time; and the combined learning designs (mixed, semi-presential, hybrid methods), which have been discussed and, in the case of nursing undergraduate courses, cause some concern.

This trend in the use of educational technologies, motivated by an expressive incorporation of the culture of innovation, must not be confused by the omnipresence of learning in which the student learns at anytime, anywhere and with any technological device. Technologies are seen as environments or means suitable for open, collaborative, flexible and contextualized learning, allowing the social construction of knowledge, formal, informal or non-formal, respecting the pedagogical and didactic conception to be implemented ${ }^{(9)}$.

Remote teaching adopted in times of pandemic can be configured in two styles: the emergency and the intentional. The term Emergency Remote Teaching has been used for a long time in crisis situations, catastrophes and is configured as a temporary change. Everything returns to normal at the moment when the crisis has passed or diminished. It is remote because students and teachers cannot go to the classroom and emergency since there was no time for planning; no one was prepared for this type of teaching. It is important to highlight that, in remote emergency teaching, the same teachers, the same students and the same number of students continue, and the teacher is the one who creates and organizes their classes, intermediates via technology with the students ${ }^{(9-10)}$.

However, when you want to move forward in terms of the quality of learning, it is important to move out of this emergency remote teaching and into intentional remote teaching. In the latter, the teaching staff, the pedagogical team and the managers think and prepare this modality. It has the intentionality of learning and not simply the delivery of content or delivery of lessons to have the effectiveness of that learning. There is an organizational process of this teaching ${ }^{(9-10)}$. Strategies are centered on learning.

It is highlighted that remote teaching is not EaD. Distance learning has a method, a structure. The content is usually prepared to order, and the tutor is usually not the one who prepared that content. EaD teaching does not allow an interaction, classes are recorded, the tutor is present only to clarify doubts, activities and teaching materials are standardized and, as a rule, evaluations and tests are produced and corrected on a scale ${ }^{(9)}$.

One cannot accelerate the adoption of technologies that limit the measurement of learning, much less think that such technologies can replace human care. The positioning remains contrary to $E a D$ training for nursing undergraduate courses. It is believed, for the nursing area, in the formation of quality, in person, that provides the precocious insertion of the students in the scenes of the practice.

The literature states that in the midst of the crisis caused by the pandemic, it has become a challenge to continue planning for such an uncertain future. However, the university and educators have obligations to society to think long term about issues related to how to recover from this pandemic, keeping the quality and clinical practice safe in the training of the student. COVID-19 has been a lesson on equity, leadership, social justice, ethics and patient care, thus forever changing the educational landscape around the world(7).

There is much to discuss about the challenges of nursing training in face of this pandemic in the search for strategies to maintain and strengthen training in order to qualify professionals who will be placed in the job market. One of the challenges is to review the pedagogical conceptions, legal bases and innovations of nursing education.

It is worth mentioning that, through Ordinances n. 343 (March 17, 2020) and 345 (March 19, 2020), the substitution of practical activities, professional activities, internships and laboratories by classes that use ICT was sealed. However, these legal provisions were revoked and replaced by Ordinance No. 544 of June 16, 2020. The new ordinance authorizes, on an exceptional basis, the replacement of in-person classes by classes that use ICT by December 31, 2020. In addition, it makes more flexible the possibility of practical activities and internships, as long as they comply with the National Curricular Guidelines of the respective courses.

About this authorization with flexibility, it is important to warn about the damage to health training, which will remain in this perspective without the integration teaching-servicemanagement-community. We cannot trivialize health training: we need to assume our social responsibility with its quality. Even knowing that the authorization with flexibility is not mandatory, but optional, it is worrying to imagine it being practiced on a large scale by the HEls.

\section{THE RETURN TO THE "NEW NORMALITY": NEW STRUC- TURING AXES AND LEGAL NORMS}

The possibilities for the so-called post-pandemic period are many. In these times, new formats and artifacts for teaching will be applied. And so, it is believed that for the return to activities it will be necessary to Re-design, Remodel, Reconfigure the teaching plans (The three Rs).

A necessary aspect is the expansion of the structuring axes for the teaching learning process. If before the pandemic, the epistemological, pedagogical and methodological axes predominated, in the post-pandemic the epidemiological, technological and psychological axes will have to be incorporated with more density.

Another aspect to consider is Opinion No. 5, of June 1, 2020, of the National Education Council, which expressed itself on the school calendar, minimum workload to be fulfilled, calculation of activities not in person for the purpose of meeting the minimum annual workload, due to the COVID-19 pandemic. The regulations have made the requirement to comply with the school calendar exceptionally flexible by exempting educational establishments from the obligation to observe the minimum number of days of actual school work, with the educational systems being responsible for approving specific normative provisions in this regard. This Ordinance allows the insertion of non-presential activities in the scope of the theoretical and practical pedagogical activities in all courses, de-characterizing specificities of formation of the 
professions of the health area. Activities related to the focus of care must include welcoming the patient, family and community and are impossible to carry out in a non-presential way. The use of technologies should be incorporated to assist the teaching process, and not replace face-to-face teaching, but to strengthen it, as well as to consolidate future use in a manner consistent with quality training.

Anxiety is another aspect to be considered by HEls, as it is said to be prevalent among Nursing students, even under normal circumstances; therefore, in view of the current situation, one must be attentive. A study in Israel points out that the students of Nursing started to experience a "reality of economic uncertainty, fear of infection, challenges of distance education, lack of individual protection equipment (PPE) at work, etc."(10). In this investigation, a prevalence of moderate and severe anxiety of $42.8 \%$ and $13.1 \%$, respectively, was reached. One of the significant factors pointed out was the fear of infection. The study emphasizes that nursing courses can act to avoid student anxiety by offering, for example, high quality teaching strategies and encouraging and supporting students in such a challenging period ${ }^{(10)}$.

It is also considered of extreme relevance to discuss in the HEls some issues necessary to face the return to the "new normality", namely: How to welcome students, teachers and technicaladministrative staff? What procedures should be adopted to ensure healthy and safe environments in the multiple institutional spaces? What tools will be used to map the needs of the academic community regarding, for example, access to equipment and internet networks? Does the academic community have a command of ICTs? It needs training/updating?

In times of post-pandemic, it is necessary to be aware of the lines of inequalities, because, among other events of great impact on societies, pandemics can also accelerate such lines. These and many other issues are already challenging. What is glimpsed for nursing education is the emergence of interface technologies that articulate the physical with the digital and that broaden debate, exchange of experiences, interaction, reflection and critical thinking.

\section{FINAL CONSIDERATIONS}

It is concluded that longstanding challenges have emerged with the pandemic, and the processes of acceleration, change and paralysis have marked education in these times. Moreover, epidemiological, technological and psychological aspects must be more valued in the return to activities. For nursing education, there is the emergence of interface technologies that articulate the physical with the digital and that broaden the debate, exchange of experiences, interaction, reflection and critical thinking.

The nursing care is presential and indispensable. Thus, the formation of professionals to take care of human lives requires knowledge, skills and attitudes in the integration teaching servicecommunity and interprofessional work.

\section{REFERENCES}

1. World Health Organization. Coronavirus disease 2019 (COVID-19) - Situation Report 67 [Internet]. Geneve: WHO; 2020 [cited 2020 Mar 27]. Available from: https://www.who.int/docs/default-source/coronaviruse/situation-reports/20200327-sitrep-67-covid-19. pdf?sfvrsn=b65f68eb_4

2. Jackson D, Bradbury-Jones C, Baptiste D, Gelling L, Morin K, Neville S, et al. Life in the pandemic: some reflections on nursing in the context of COVID-19. J Clin Nurs. 2020;00:1-3. doi: 10.1111/jocn.15257

3. Associação Brasileira de Enfermagem. Nota da Aben Nacional em relação à ação estratégica "O Brasil conta comigo"[Internet]. Brasília: ABEn; 2020 [cited 2020 Mar 27]. Available from: http://www.abennacional.org.br/site/wp-content/uploads/2020/04/Nota-Aben-educacao2.pdf

4. Ministério da Educação (BR). Cadastro Nacional de Cursos e Instituições de Educação Superior: Cadastro e-MEC[Internet]. 2020[cited 2020 Mar 27]. Available from: http://emec.mec.gov.br

5. Ministério da Saúde (BR). Conselho Nacional de Saúde. Resolução n. 573, de 31 de janeiro de 2018 [Internet]. 2018[cited 2020 Jun 08] Available from: http://conselho.saude.gov.br/resolucoes/2018/Reso573.pdf

6. Dewart G, Corcoran L, Thirsk L, Petrovic K. Nursing education in a pandemic: Academic challenges in response to COVID-19. Nurse Educ Today. 2020;92:104471. doi: 10.1016/j.nepr.2020.102809

7. Nietsche EA, Leopardi MT. O saber da enfermagem como tecnologia: a produção de enfermeiros brasileiros. Texto Contexto Enferm. 2000;9(1):129-52.

8. Tomasinho P. Ensino Remoto Emergencial: A Oportunidade da Escola Criar, Experimentar, Inovar e se reinventar. Medium [Internet] 2020[cited 2020 Jun 09]. Available from: https://medium.com/@paulotomazinho/ ensino-remoto-emergencial-a-oportunidade-da-escola-criar-experimentar-inovar-e-se-reinventar-6667ba55dacc

9. Holges C, Moore S, Lockee B, Trust T, Bond A. The difference between emergency remote teaching and online learning. Educ Rev[Internet]. 2020 [cited 2020 Jun 09]. Available from: https://er.educause.edu/articles/2020/3/ the-difference-between-emergency-remote-teaching-and-online-learning\#fn 1

10. Savitsky B, Findling Y, Ereli A, Hendel T. Anxiety and coping strategies among nursing students during the covid-19 pandemic. Nurse Educ Today. 2020;46:102809. doi: 10.1016/j.nepr.2020.102809 